\title{
Critical Approaches to GIS and Spatial Mapping in Indonesia Forest Management and Conservation
}

\author{
Asrul Sidiq ${ }^{1,2 *}$ \\ 1 Ph.D. student, Crawford School of Public Policy, Australian National University; asrul.sidiq@anu.edu.au \\ 2 Universitas Syiah Kuala; asrul.sidiq@unsyiah.ac.id \\ * Correspondence author: asrul.sidiq@anu.edu.au; Tel.: +61-403-841-055
}

\begin{abstract}
The conventional Geographic Information Systems (GIS) and spatial mapping techniques fail to understand a spatially complex forest area. This is because forest landscapes cannot be easily mapped into a two-dimensional map, which is usually used in spatial planning. In addition, planning maps are the fundamental factors of land grabbing issues. To solve this problem, counter-mapping arises at the local level as a tool to overcome the problem of land grabbing in forest areas in Indonesia. Counter mapping is defined here as part of a broader term under participatory mapping or citizen mapping. However, counter-mapping also faces critiques in terms of different epistemological and socio-economic-political conditions at the local level. This article elaborates the use of GIS and spatial mapping methods within a 'critical' social science approach based on literature review and field experiences. This article also aims to analyze counter-mapping as a 'tool' to solve the forest land-use problem, which can contribute to the choice of policy instruments in forest management and conservation in Indonesia.
\end{abstract}

Keywords: spatial planning; land use mapping; forest policy

\section{Introduction}

Geographic Information Systems (GIS) are computer-based systems used to collect, store, analyze, display, and retrieve data for various purposes related to mapping and planning (Burrough et al., 2015). As an overall system, GIS integrates spatial data and non-spatial data into one system that offers a consistent framework for the analysis of geographical data. Therefore, GIS can link between activities and geographical proximity.

These questions are the common inquiries that GIS and spatial mapping try to answer: can it be mapped? (mapping); what is there? (location); where is it? (condition); what has been changed since ...? (trend); what kind of spatial patterns exist? (pattern); what influences what? (system); and what if ...? (modeling). However, in the case of the 'critical' social science approach, various critiques have sought to engage on GIS and spatial mapping methods in more explicitly political terms. Roth (2007), for example, argues that social relations play an essential role in producing spatial complexity, which cannot be easily mapped into a two-dimensional map. In addition to spatial complexity, GIS applications and spatial mapping techniques need to be cautious about its political implications. For example, in my examination of trends in Indonesia, I ask how do we incorporate complex social relations like tenure dynamics within community forestry areas? How do we prevent the map from being a 'static' or 'reified' output (Peluso, 1995)? A more specific challenge involves the mapping of customary contexts in forest areas. These challenges include different ontologies and worldviews between people, privacy, and data access, 'living' conditions that shift over time, diversity conditions, and terms of empowerment. Indeed, Nietschmann (1995) compellingly argues that maps have claimed more indigenous territory than have been taken by guns.

GIS can be used to answer questions and engage with significant challenges across fields, such as forest management and conservation and spatial planning. For example, GIS is used as a tool to solve the problem of land use conflicts between customary people with plantation companies that 
obtain business permits from the government. In such cases, spatial planners overlay state forest maps from the Ministry of Environment and Forestry (MoEF) and non-forest estate land databases from the Ministry of Agrarian Affairs and Spatial Planning/National Land Agency (ATR/BPN) with settlement maps of customary people using GIS as data for creating spatial planning maps. The MoEF is responsible for managing state forests and ATR/BPN is responsible for managing non-forest estate areas. Setyowati (2020) identifies that forest categorization in Indonesia's spatial planning system determines who has the right to access different areas for specific uses. Therefore, GIS can facilitate government control over landscapes (Peluso, 1995; Roth, 2007; Radjawali et al., 2017). In addition to this, counter-mapping has become a trend in challenging 'traditional-mapping' processes by governments in the area where overlapping tenure is common. The term countermapping became popular after Nancy Peluso researched the implementation of two different counter-mapping strategies in Kalimantan, Indonesia (Peluso, 1995).

Accordingly, spatial planning maps raise the issue of land grabbing within the forest area, depending on whose map gains formal recognition by the state. Land grabbing refers to large-scale purchases or leases by investors, governments, and individuals. For example, land use permits are often given to the provincial/regency level without the knowledge of individuals residing in the area (Radjawali et al., 2017). In such cases, state planners determine whether an area is protected forest, production forest, or a mining area, etc.

In addition, the development of mapping technology (e.g., GIS, GPS, drone, and remote sensing) has supported the increase of counter-mapping strategies. In the case of Indonesia, counter-mapping is usually used to challenge spatial planning documents produced by the state. Both NGOs and communities can conduct counter-mapping. For instance, civil society in West Kalimantan formed the 'Civil Society Coalition for a Just and Sustainable Spatial Plan' and together with the communities conducted counter-mapping to challenge particular land categorizations in the new spatial plan (Rencana Tata Ruang Wilayah / RTRW) in West Kalimantan, Indonesia.

This brief article consists of a target review to better understand and place the use of GIS and spatial mapping methods within a 'critical' social science lens. This policy forum paper thus aims to analyze counter-mapping as a 'tool' to solve forest land-use disputes especially in terms of access and rights to forest land and resources. I therefore elaborate how GIS is used to enclose areas within Indonesia spatial planning system, and how counter-mapping strategies have sought to push back on this issue.

\section{Spatial planning on forestry in Indonesia}

RTRW is an essential document in forest management and conservation in Indonesia because it covers all the land use planning elements of both state forests (Kawasan Hutan) and non-forest estate areas (Area Penggunaan Lain). Furthermore, every land use planning initiative in Indonesia follows the RTRW document because it is the formal legal document of development policy in Indonesia (Ardiansyah et al., 2015). Indonesia has different levels of RTRW, beginning from national (Indonesia), provincial, to district (kabupaten/kota), and more detailed spatial planning initiatives are called Rencana Detail Tata Ruang (RDTR). Each level of the RTRW has a different map scale. A smaller amount of area with a larger amount of detail is represented by large scale maps. For instance, provincial RTRWs should align with the national RTRW, but with more detailed information because the scale of maps at the provincial RTRW is finer than the national RTRW.

The dualism of land management in Indonesia between MoEF and ATR/BPN usually leads to overlapping land tenure arrangements and inefficient planning process (World Bank, 2020). In the process of making the RTRW, planners use forest zone maps (Peta Kawasan Hutan) from MoEF as the basis for spatial planning for state forest land uses. If there is a conflicting/overlapping land tenure between MoEF and ATR/BPN, the state should conduct what is called "paduserasi." Paduserasi is an activity to synergize the land use plan in state forest area to resolve the differences in land use between two government agencies. However, paduserasi does not resolve land use disputes between the state and local communities. 
Spatial planning is an instrument to guide sectors related to land uses, both in terms of development and protection areas. In the RTRW, forestry lands are classified into a conservation area, protected forest, and production forest. This classification is useful when the land is being planned by state planners. The classification allows planners to identify the different forest management objectives and conservation initiatives to be implemented in the different forest areas (Appanah, 2016). However, it is increasingly recognized that spatial planning from the state does not always suit the socio-ecological nature of forest ecosystems because the forest is a 'living' landscape formed by multiple social actors and networks (Van Oosten et al., 2014). According to Robinson et al. (2017) and Cockburn et al. (2018), the landscape is defined as place-based socialecological structures that emerge from people's interactions with land-based environments and the natural resources they produce through their values and institutions.

The government assumes that land conflict occurs when there is no updated map reference as the primary basis for development at the local level. Therefore, a mandatory step in social forestry programs in Indonesia is to ensure that local communities are actively involved in participatory mapping. Indonesia launched a new round of reform called 'Social Forestry' (Perhutanan Sosial) in 2015 to provide access to the communities in utilizing state forest areas to support community livelihoods and improve forest conservation and rehabilitation. This reform happened because the previous forest management model experiences through concessions and plantations in Indonesia did not guarantee local communities' access in a sustainable manner (Moeliono et al., 2017). However, De Royer (2018) claims that local communities were rarely involved during forestry mapping.

McGregor et al. (2014) states that establishing a map with a clear spatial arrangement and tenure rights could increase the sense of security of local people. However, every department at the local, provincial, and national levels in Indonesia has different types of thematic maps used as a basic map for determining forest licensing processes, which can lead to land disputes (Astuti \& McGregor, 2017). In addition to this, one of the strategies from the government is to incorporate participatory mapping in the process of implementing the one map policy in Indonesia. The One Map Policy in Indonesia aims to integrate information on land use, land ownership, private ownerships, and customary rights. In this light, there is an urgent need to stimulate and facilitate initiatives from the bottom-up in order to ensure that local voices are not erased by the map.

The current spatial planning maps are developed based on satellite imagery as the underlying map. The problem of satellite imagery however, is the resolution of satellite pictures, which cannot portray the detail of local conditions. Satellite imagery results sometimes create generalizations on the map. Therefore, map creators need to verify and check directly in the field in a process commonly described as ground truthing. For example, the target of the One Map Policy in Indonesia is to have one basic map for all over Indonesia with the scale of the map only 1:50.000. Nevertheless, fined scale and detailed maps are needed to cover many things on the ground. Currently, Indonesia still does not have a standard basic map as a primary reference for all the areas of Indonesia since the one map policy program is still in process.

Following this issue, the importance of a standard map as the basis for reference has become critical. Furthermore, the One Map Policy has become a national program through Presidential Regulation 9/2016 on the acceleration for the implementation of the One Map Policy. However, the maps produced by state authorities in Indonesia still fail to capture tenure dynamics and social relations. Therefore, spatial planning systems can employ a political ecology approach that focuses on examining contests over control and access to natural resources through exploring different actor-positions, claims to property rights, and livelihoods (Peet \& Watts, 2004). In political ecology, the environment is not the simple backdrop to global transformations; rather, nature itself is an active agent (Robbins, 2011).

Based on my experience working as a spatial planner helping to draft the Regional Spatial Plan of Aceh Province (RTRW Aceh) in 2009, and subsequently working on the revision of the RTRW Aceh in 2019 , the complexity of tenure is extremely difficult to be accommodated with the current spatial planning system in Indonesia. This is because spatial planning mapping processes by the state does not integrate customary territory. In Aceh, forest and agricultural lands have been managed by 
customary rules for access and benefit distribution for a long period (McCarthy 2007). While local communities continue to practice customary forest tenure arrangements, they typically do not have formal property rights over forest areas (Setyowati 2020). Therefore, some NGOs, together with customary communities in Aceh still ask for the inclusion of customary territory (Mukim) into the RTRW, and the process of RTRW revision is still ongoing. Mukim is a customary adat territory under one management regime that was originally part of the Aceh Sultanate system. However, the rigidity of the territories categorization in laws on spatial planning system makes it difficult to accommodate Mukim in RTRW Aceh. Even though Mukim is recognized in the Law on Governing Aceh (Law 11/2006), it still conflicts with other national laws and regulations on spatial planning in Indonesia. For instance, the Village Governance Act (Law 5/1979, revised with the Law 6/2014) deteriorated the existence of Mukim in forest governance (Setyowati 2020). This is one of the reasons on the delay on the process of finalizing the RTRW Aceh revision that began since 2019.

Furthermore, spatial planning maps are the fundamental factors of land grabbing issues in Indonesia (Radjawali et al. 2017). For instance, even though ATR/BPN Regulation 1/2018 on guidelines for drafting spatial plans recognizes customary forest areas in the document, customary forest areas have not been part of the map legend in the spatial planning maps. In addition, the regulation mentions the importance of customary people aspirations as the source of data and information in making the RTRW. However, it is difficult to collect all the data and information on the ground because of limitations from the RTRW drafting process, which only allows 18 months maximum (Government Regulation 21/2021). As Indonesia adopts a regulatory planning systems, the spatial planning maps are so powerful in reorienting what is possible on the ground, which facilitates potential land grabbing if spatial planning maps do not capture dynamics at scale and on the ground. Therefore, this trend has also promoted increasing sophistication and a growing movement of counter-mapping trends in Indonesia to challenge the conventional mapping system (Peluso, 1995; Radjawali et al., 2017).

\section{Community-based counter-mapping}

Community-based counter mapping is part of a broader term under participatory mapping or citizen mapping (Radjawali et al., 2017). Two criticisms of counter-mapping relate to different epistemological and socio-economic-political conditions at the local level (Peluso, 1995; Roth, 2007; Radjawali et al., 2017). Firstly, there are two main points on this epistemological view. The first is that many GIS and spatial mapping (including counter-mapping) follows the 'western' map-making approach, which is unsuited to the third world 'politics of mapping', a term used by Peluso. The 'politics of mapping' reflects the history of mapping and its location-specific political contexts that vary between places (Peluso, 1995). Therefore, the different contexts between locations require different approaches because not 'one size fits all'. The second issue is that the process of mapping itself would shift the understanding and values of societies involved by 'freezing' the social dynamics. As Indonesia uses regulatory spatial planning systems such as the RTRW as the legal formal basis of spatial planning, it can restrict the dynamics of 'customary law' that is still prevalent in some parts of forested areas in Indonesia. However, Indonesia may move to more discretionary spatial planning systems with the current omnibus law on job creation (Law 11/2020). At this stage it is unclear, but I believe it will become increasingly challenging for a country like Indonesia to apply the discretionary spatial planning system. Based on my experience working with the Coordinating Board of the Aceh Spatial Planning (Badan Koordinasi Penataan Ruang Aceh/BKPRA), an ad-hoc institution for spatial planning coordination, the main challenge is in the good governance implementation. Therefore, the discretionary system is more challenging to be implemented.

Secondly, counter-mapping might affect socio-economic and political issues at the local level because it can create new hierarchies, as Roth (2007) argues that GIS and spatial mapping can misrepresent community activities as being spatially fixed. As a result, counter-mapping by the community defines changes in how the community manages its land, instead of describing and visualizing current land-use conditions.

Radjawali et al. (2017) argue that contemporary mapping needs specific technical tools and computer skills that might harm local communities over other actors and stakeholders. This 
phenomenon is usually called 'elite capture' which is a common occurrence in rural areas of Indonesia. Elite capture in the forestry sector often happens because of uneven access to information and knowledge (De Royer, 2018).

Radjawali et al. (2017) try to solve these problems using Unmanned Aerial Vehicle (UAV), or what are more commonly called drones. Drone mapping shows effective outputs in strengthening local communities' legal and political claims. The drone technology serves as a tool to include people in the whole process of mapping because it is fun and leads to more questions during the process. Further, this technique is cheaper and easier to use compared to satellite imagery. The key is the transferability of skills to local people.

However, drone-mapping also has its problems. Based on my experience conducting drone mapping in Indonesian villages, this technology is not easily transferred to local people. For example, it also requires specific skills and tools that are not common in rural areas. In addition, when we train intensively select local people until they understand, the issue of transferability and sustainability are still difficult to maintain. It requires a continuous learning process applicable to the field. Otherwise, this method will not be sustainable. In this sense, counter-mapping using drones will be difficult to become a 'science of the masses' to borrow the phrase from Peluso in her paper.

Roth (2007) suggests the potential of multi-mapping for village land-use mapping. In the first part of her mapping method, the mapping starts with the land as the unit of analysis and interviews village leaders and other key informants. Second, moving the unit analysis into the household while also doing the household interview to ensure all households are covered in the map. Also, Roth suggests the importance of spending a long time in the field during the map-making process. Initially, most of the researchers using this method only spend several months, if not weeks in the field. Roth spent more than nine months when she conducted her research.

Based on my experience as a spatial planner working with the government, most of the time, spatial planners in Indonesia only spend a little time in the field for spatial planning map-making. This is because of the limitations in finalizing the RTRW. Therefore, some NGO and villagers and planners say that the map produced by the state authorities is the result of 'spidologi'. Spidol means marker, and logi means knowledge. So, 'spidologi' is the knowledge of marking or mapping something using a marker without really looking into the field.

\section{Conclusion}

Land management in Indonesia is closely related to spatial planning by the state. This top-down spatial mapping from the government has resulted in conflicts over land in many rural and forest areas in Indonesia. The main critique on 'conventional' GIS and spatial mapping by the state is that this approach fails to incorporate the complex social systems into the map. In addition, countermapping arises as a tool to solve the forest land-use problem, especially in terms of access and rights to forest land and resources. The positive view of counter-mapping is to correct and combat such coercion, one-sidedness, and fight for the acceptance of differing views, both political and legal statements (Peluso, 1995; Roth, 2007; Radjawali et al., 2017). However, different epistemological and socio-economic-political conditions at the local level are the main critiques on the implementation of counter-mapping.

There are many challenges in mapping real space and spatiality into a two-dimensional map. The conventional GIS and spatial mapping techniques fail to understand a spatially complex forest area. However, a two-dimensional map is also essential. GIS and spatial mapping need to start incorporating social relations and society-environment dynamics into the map. Therefore, it is crucial to combine technological advancement and the 'political ecology' approach with GIS and spatial mapping.

Finally, the map is not the final output that we want, but it is the method to achieve several outputs. It is important to involve local communities in conducting a GIS and spatial mapping approach. It seems that the state should work more closely with local communities to create landuse maps. Local communities are not solely the mapping programs' objects, but they are the main actors for land-use planning. 
Conflicts of Interest: The author declares no conflict of interest.

\section{References}

Appanah, S. (2016). Forest landscape restoration for Asia-Pacific forests. RECOFTC. Retrieved from https://www.recoftc.org/publications/0000150

Ardiansyah, F., Marthen, A. A., \& Amalia, N. (2015). Forest and land-use governance in a decentralized Indonesia: A legal and policy review (Vol. 132). CIFOR. https://doi.org/10.17528/cifor/005695

Astuti, R., \& McGregor, A. (2017). Indigenous land claims or green grabs? Inclusions and exclusions within forest carbon politics in Indonesia. The Journal of Peasant Studies, 44(2), 445-466. https://doi.org/10.1080/03066150.2016.1197908

Burrough, P. A., McDonnell, R., McDonnell, R. A., \& Lloyd, C. D. (2015). Principles of geographical information systems. Oxford university press.

Cockburn, J., Cundill, G., Shackleton, S., \& Rouget, M. (2018). Towards place-based research to support social-ecological stewardship. Sustainability, 10(5), 1434. https://doi.org/10.3390/su10051434

De Royer, S., Van Noordwijk, M., \& Roshetko, J. M. (2018). Does community-based forest management in Indonesia devolve social justice or social costs?. International Forestry Review, 20(2), 167-180. https://doi.org/10.1505/146554818823767609

McCarthy, J. F. (2007). The Demonstration Effect: Natural Resources, Ethnonationalism and the Aceh Conflict. Singapore Journal of Tropical Geography, 28(3), 314-33. https://doi.org/10.1111/j.1467-9493.2007.00304.x

McGregor, A., Weaver, S., Challies, E., Howson, P., Astuti, R., \& Haalboom, B. (2014). Practical critique: Bridging the gap between critical and practice-oriented REDD+ research communities. Asia Pacific Viewpoint, 55(3), 277-291. https://doi.org/10.1111/apv.12064

Moeliono, M., Thuy, P. T., Bong, I. W., Wong, G. Y., \& Brockhaus, M. (2017). Social Forestry-why and for whom? A comparison of policies in Vietnam and Indonesia. Forest and Society, 1(2), 7897. https://doi.org/10.24259/fs.v1i2.2484

Nietschmann, B. (1995). Defending the Miskito Reefs with maps and GPS: mapping with sail, scuba, and satellite. Cultural survival quarterly, 18(4), 34-37.

Peluso, N. L. (1995). Whose woods are these? Counter-mapping forest territories in Kalimantan, Indonesia. Antipode, 27(4), 383-406. https://doi.org/10.1111/j.1467-8330.1995.tb00286.x

Peet, R. \& Watts, M. (2004). Liberation ecologies: environment, development, social movements. Routledge.

Radjawali, I., Pye, O., \& Flitner, M. (2017). Recognition through reconnaissance? Using drones for counter-mapping in Indonesia. The Journal of Peasant Studies, 44(4), 817-833. https://doi.org/10.1080/03066150.2016.1264937

Robbins, P. (2011). Political ecology: A critical introduction. John Wiley \& Sons.

Robinson, L.W., Ontiri, E., Alemu, T., \& Moiko, S.S. (2017). Transcending landscapes: Working across scales and levels in pastoralist rangeland governance. Environmental Management, 60(2), 185-199. https://doi.org/10.1007/s00267-017-0870-z

Roth, R. (2007). Two-dimensional maps in multi-dimensional worlds: A case of community-based mapping in Northern Thailand. Geoforum, 38(1), https://doi.org/10.1016/j.geoforum.2006.05.005

Setyowati, A. B. (2020). Making territory and negotiating citizenship in a climate mitigation initiative in Indonesia. Development and Change, 51(1), 144-166. https://doi.org/10.1111/dech.12541

Van Oosten, C., Gunarso, P., Koesoetjahjo, I., \& Wiersum, F. (2014). Governing forest landscape restoration: Cases from Indonesia. Forests, 5(6), 1143-1162. https://doi.org/10.3390/ 55061143

World Bank. (2020). Indonesia: Systematic country diagnostic update. The World Bank Group. https://documents1.worldbank.org/curated/en/717421594076964759/pdf/Indonesiaystematic-Country-Diagnostic-Update.pdf 